\title{
Standard Language(s)
}

James Costa

Sorbonne Nouvelle/Lacito, France

Abstract: Language standardization is approached here through the main debates that inform reflection on majority and minority language standardization in Europe and beyond. Beyond the main contemporary debates, it frames standardization as the outcome of a unique historical, philosophical, and political project that originates in seventeenth-century Europe and which sought to stabilize knowledge beyond the divergences between Protestants and Catholics that had led to war and destruction throughout the century. Standard languages are, in that sense, the descendants of the early attempts to create universal language schemes devoid of indexicals of place and social or religious origins. This entry also asks if those processes, born among speakers of now dominant European languages, can be transposed to minority language settings worldwide.

Keywords: language ideology; majority and minority languages; standardization

Outside the realm of language, the term "standardization" may refer to several processes, from the creation of a common banner to be followed to the establishment of a model to be imitated, and to "the imposition of uniformity upon a class of objects" (Milroy 2001, 531) - such as the standardization of weights and measures. However, all three types of standard make reference to a large extent to the necessity of a certain authority that generates belief in the value of the standard, be it a real object or a virtual project. As a linguistic process, standardization is often ubiquitous, ambiguous, and may refer to different processes and several strands of debates. 


\section{Classical approaches to standardization: Technical, ideological, and historical}

Standardization can, in its simplest form, be defined as the imposition of a supradialectal norm to a language community, the diffusion of a particular register that, through its associations with the state and with education, comes to represent the best and most legitimate form of a given language. Current works on linguistic standardization can be organized around three main axes: first, a technical perspective which seeks to explain how standards came to be and came to be imposed (and how, consequently, new standards can be instated); second, a more political or ideological orientation that views standards as the imposition of one linguistic variety through authority and symbolic violence; and third, a more historical approach that seeks to understand how standardization is the ambivalent product of late medieval and early modern material and social concerns emerging from philosophy on the one hand and the rise of political science and philology on the other. While this tripartition constitutes a simplification of current works on standardization, it remains nonetheless useful as a lens to understand how contemporary debates unfold, and how they might contribute to explaining language ideological debates in major state languages as well as in minority/minoritized language contexts.

The first, more technical approach derives largely from the work of the Norwegian American scholar Einar Haugen, who described the rise and establishment of standard languages through the following four stages: selection, codification, implementation, and elaboration (see Deumert and Vandenbussche 2003 for a discussion of the model). Selection entails choosing a particular regional, social, or composite linguistic variety to be used as a base for the standard. Codification entails the creation of a normative set of texts such as dictionaries and grammars to be used in the process of standardization, in particular in education and other government services. Implementation concerns the various political measures taken to ensure that the prescriptions are carried out and respected 
throughout the various functional areas in which the standard is needed or felt to be needed. Elaboration deals with corpus planning and the necessity to develop terminology for the new uses to which the new standard variety will be confronted. However, while this model might prove an adequate post hoc rationalization or working simplification of how languages such as French or English came to be standardized, it explains little as to why such an impetus was ever needed, how and where it originated, and why large populations came to be convinced by such a necessity - or indeed how a belief in the value and validity of a proposed standard form is achieved. This model has nevertheless been used as the basis for the development of standard forms of minority languages from Europe to Latin America (see also Darquennes and Vandenbussche 2015).

A second approach follows Bourdieu's work on legitimate language, and holds a more political view on standardization. This approach describes standardization as essentially a process of reduction of linguistic diversity aimed at ensuring the stability and fixedness of a particular linguistic variety over space and time, casting prestige upon its users, and asserting that it is the (often sole) correct form of a given language (Milroy 2001). In that sense, standardization amounts to creating or crafting what variety speakers and learners alike will ultimately deem to be the language. According to this perspective, language standards never fully exist except as projects, and standardization is an ever-ongoing, ideologically motivated endeavor, tied both to processes of societal hierarchization, to the monoglot standard ideologies of nation-states (Silverstein 1996), and to genealogies of language and people reaching as far back in time as possible. In that sense, standardization is part of the charter myth of modern nation-states. The standard ultimately stands for the entire language and other variants can only be viewed as peripheral dialects or rustic patois related to the language, remnants from times long gone or the manifestation of a lack of integration in the national community (in the case of the language of poor suburban areas of France for example).

The historical perspective raises the question of whether all linguistic norms are linguistic 
standards. For a standard to be fully recognized as such, the source of its authority needs to have become naturalized in such a way that it cannot be disputed. The case of English is prototypical in that sense: in the nineteenth century the authority of the standard was described in various manuals as derived from the language used in the Bible (Crowley 2003), rather than from its use by a particular class of people. This, along with several historical studies, points to the origins of standardization in written rather than oral language (see Joseph 1987), in particular in European chanceries from the end of the Middle Ages onward.

Standardization can thus be thought of as an indirect consequence of political unrest that oversaw the philosophical and institutional quest for stability, and for a type of truth that would be true independent from its utterer, whether they be Catholic and Protestant. Oral as well as written linguistic models, koines, administrative scriptae, are indeed common through time and space. Those, however, are only particular registers imbued with certain types of authority connected with certain forms of highly situated knowledge and designed for particular usages, be they literary, legal, or regal. Not all linguistic norms, however, can be called standard languages. The term "standardization" is perhaps best used to refer to the types of social and linguistic processes that emerged at the junction of several historical processes, including: the invention and diffusion of the printing press; the Protestant Reformation and the early translation of the Bible into vernaculars such as English (1526 and 1535), French (1530, 1535 and 1550), German (1534) or, later, Welsh for example (1588); and subsequent wars of religion in the seventeenth century, ending with the 1538 Peace of Westphalia.

In this respect, standardization can be viewed as an outcome of the necessity to find universal truth and certainty beyond the religious divide in Europe, which, first formulated by Descartes, Bacon, or Locke, was to lead to the separation of nature from society - thus enabling the creation of natural sciences disconnected from the vicissitudes of society. One consequence of this separation was the need to formulate universal truth linguistically (Bauman and Briggs, 2003). The birth of new publics in 
the realm of science, and later in the realm of politics in the latter half of the eighteenth century and in the nineteenth century, thus gave rise to a quest for ways of speaking that were both unambiguous, universal, and devoid of obvious indexicalities of place or religious affiliation in particular - in other words, decontextualized. While the first attempts to solve this conundrum were through the creation of invented, universal language schemes such as that of John Wilkins in England, political demands led to the universalization of certain national vernaculars, with French being the paradigmatic example after the French Revolution during the last decade of the eighteenth century.

It was the cosmopolitanism of the Enlightenment, in Scotland, England, France, or Germany, which thus paradoxically imbued certain languages, rather than speech itself, with the attributes of universalism to the detriment of other languages. Those languages viewed as universal were thus by necessity decontextualized so as to permit the ideal participation of citizens to new public spheres in a way that would make their speech devoid of indexicals of origin, social or geographic. This decontextualized aspect would in turn provide the basis and rationale for languages such as French and English to become teachable to cultural elites overseas as part of the colonial projects of France, Great Britain, or the Netherlands. To problematize standardization in those terms is thus not merely to enquire into a linguistic process, but into a long history that has shaped, and continues to shape, how modern societies are imagined and how they are imagined as bounded wholes. Standardization, with the types of social stratification it entails, the rights and duties between individuals it involves, is thus a particular, historically situated type of social relation.

\section{Majority and minority languages}

Because of the diffusion of the standard language model among Europe's major languages and its generalization in education, it has been taken as a model for language development by many minority or minoritized language movements since at least the mid-nineteenth century, not only in Europe but 
across the world (see Lane, Costa, and De Korne 2017 for a number of case studies and a discussion by Susan Gal). A historical approach linking the rise of standards to nation-states as well as to a voice from nowhere raises at least two main questions with respect to minority languages: first, is standardization desirable, and if so, from whose perspective? And second, is it in fact possible at all beyond the establishment of common orthographic norms? Can minority language standards ever achieve the type of decontextualization (and naturalization) that is the hallmark of standard languages such as French or English? Drawing on the historical development of standard languages, Woolard (in particular 2008) suggests a framework that opposes anonymity, the capacity to articulate a voice from nowhere, and which she associates with large languages, and authenticity, the preserve of minority languages whose value would rest in its ties to a particular community. Such a framework suggests that minority languages, to strive toward standardization, should renounce those ties at least partly, so as to become learnable, for example, by outsiders. Yet by so doing, minority languages risk losing what makes the language valuable to their speakers and advocates in the first place, while renouncing standardization risks jeopardizing efforts to use the language in education (see Costa 2015) and thus to increase the number of speakers.

\section{References and Further Reading}

Bauman, Richard, and Charles L. Briggs. 2003. Voices of Modernity: Language Ideologies and the Politics of Inequality. Cambridge: Cambridge University Press.

Costa, James. 2015. "Can Schools Dispense with Standard Language? Some Unintended Consequences of Introducing Scots in a Scottish Primary School." Journal of Linguistic Anthropology 25 (1): 25-42. https://doi.org/10.1111/jola.12069.

Crowley, Toney. 2003. Standard English and the Politics of Language. Basingstoke and New York: Palgrave MacMillan. 
Darquennes, Jeroen, and Wim Vandenbussche. 2015. "The Standardisation of Minority Languages Introductory Remarks." Sociolinguistica 29 (1): 1-16. https://doi.org/10.1515/soci-2015-0003.

Deumert, Ana, and Wim Vandenbussche. 2003. "Standard Languages Taxonomies and Histories." In Germanic Standardizations: Past to Present, edited by Ana Deumert and Wim Vandenbussche, 114. Amsterdam: John Benjamins.

Joseph, John E. 1987. Eloquence and Power: The Rise of Language Standards and Standard Languages. New York: Blackwell.

Lane, Pia, James Costa, and Haley De Korne, eds. 2017. Standardizing Minority Languages: Competing Ideologies of Authority and Authenticity in the Global Periphery. London: Routledge.

Milroy, James. 2001. "Language Ideologies and the Consequences of Standardization." Journal of Sociolinguistics 5 (4): 530-555. https://doi.org/10.1111/1467-9481.00163.

Silverstein, Michael. 1996. "Monoglot 'Standard' in America: Standardization and Metaphors of Linguistic Hegemony." In The Matrix of Language: Contemporary Linguistic Anthropology, edited by Donald Brenneis and Ronald MacAulay, 284-306. Boulder, CO: Westview.

Woolard, Kathryn A. 2008. "Language and Identity Choice in Catalonia: The Interplay of Contrasting Ideologies of Linguistic Authority." In Lengua, nación e identidad: La regulación del plurilingüismo en España y América Latina, edited by Kirsten Süselbeck, Ulrike Mühlschlegel, and Peter Masson, 303-323. Frankfurt am Main and Madrid: Vervuert and Iberoamericana. 